\author{
Abstracta Iranica \\ Abstracta Iranica Revue bibliographique pour le domaine irano-aryen \\ Volume 32-33 | 2013 \\ Comptes rendus des publications de 2009-2010
}

\title{
Florence Jullien. Xvadāhoy de Bēth-Ḥālé. Un développement du monachisme réformé à Hịira?
}

\section{Rédaction}

\section{(2) OpenEdition}

1 Journals

\section{Édition électronique}

URL : http://journals.openedition.org/abstractairanica/40848

DOI : 10.4000/abstractairanica.40848

ISSN : 1961-960X

Éditeur :

CNRS (UMR 7528 Mondes iraniens et indiens), Éditions de l'IFRI

\section{Édition imprimée}

Date de publication : 1 décembre 2013

ISSN : 0240-8910

\section{Référence électronique}

Rédaction, «Florence Jullien. Xvadāhoy de Bēth-Hālé. Un développement du monachisme réformé à Hira? », Abstracta Iranica [En ligne], Volume 32-33 | 2013, document 333, mis en ligne le 01 juillet 2016, consulté le 26 septembre 2020. URL : http://journals.openedition.org/abstractairanica/40848 ; DOI : https://doi.org/10.4000/abstractairanica.40848

Ce document a été généré automatiquement le 26 septembre 2020.

Tous droits réservés 


\title{
Florence Jullien. Xvadāhoy de Bēth- Hâalé. Un développement du monachisme réformé à Hīra?
}

\author{
Rédaction
}

\section{RÉFÉRENCE}

Florence Jullien. « Xvadāhoy de Bēth-Ḥālé. Un développement du monachisme réformé à Hiira? ». Aram 21, 2009, p. 323-343.

1 Pour les chrétiens d'Orient à l'est de l'Euphrate, Rabban Xvadāhōy compte parmi les plus grandes figures monastiques historiques, aux côtés de noms prestigieux comme ceux d'Abraham de Kashkar ou de Babaï le Grand. Aucune étude d'ensemble ne lui avait été consacrée. L'A. rassemble la documentation le concernant afin de faire sortir de l'ombre celui que Dadisho Q Qațraya désigne comme « chef illustre » du monachisme. Ce fondateur se situe au centre d'un entrelacs de cycles de traditions monastiques, ce qui pose la question d'un développement du monachisme réformé (selon les règles d'Abraham d'Izla) à Hira.

\section{AUTEURS}

\section{RÉDACTION}

Directeur de la revue et secrétariat (Paris) 